\title{
STABILITY OF ANTIOXIDANTS VITAMINS IN BEE POLLEN SAMPLES
}

\author{
Illana Louise Pereira de Melo e Ligia Bicudo de Almeida-Muradian* \\ Faculdade de Ciências Farmacêuticas, Universidade de São Paulo, Av. Prof. Lineu Prestes, 580, Bl. 14, 05508-900 Sao Paulo - SP, Brasil
}

Recebido em 7/1/09; aceito em 1/9/09; publicado na web em 24/2/10

\begin{abstract}
This study evaluated the stability of vitamins $\mathrm{C}, \mathrm{E}$ and $\beta$-carotene in six samples of bee pollen after their process, and in a one-year period of storage. After the pollen's process, there was a $67.1 \%$ increase for vitamin $C(p<0.05)$, an $18.7 \%$ loss for vitamin $E$ and $15.6 \%$ for $\beta$-carotene. Storage in freezer was the most efficient condition for the vitamins conservation; the loss in storage at room temperature (exposed or protected from light) was similar. Vitamin E appears to be better preserved during storage when compared to vitamin $\mathrm{C}$ and $\beta$-carotene.
\end{abstract}

Keywords: bee pollen; vitamins; stability.

\section{INTRODUCTION}

According to Normative Instruction No. 3, from January 19, 2001, from the Ministry of Agriculture, Livestock and Food Supply (Ministério de Agricultura, Pecuária e Abastecimento - MAPA), bee pollen is defined as the result of the agglutination of flower pollen, nectar and honeybee salivary substances, carried out by worker bees and collected at the hive's entrance. ${ }^{1}$ The bee pollen contains proteins, carbohydrates, lipids and minerals in its composition. It also contains the antioxidant vitamins (vitamins $\mathrm{C}, \mathrm{E}$ and $\beta$-carotene, as pro-vitamin A), those from B complex and vitamin D. ${ }^{2,3}$

Due to the high moisture level found in the composition of bee pollen, the process of dehydration is essential, since this moisture causes its rapid fermentation and deterioration. ${ }^{4}$ The contents of vitamins from pollen and other foods can suffer alterations with processing and storage. ${ }^{5}$ Almeida-Muradian et al., in their analysis of samples $(\mathrm{n}=10)$ of dried bee pollen collected in the Southern Region of Brazil, observed the absence of $\beta$-carotene (pro-vitamin A) and vitamin C (ascorbic acid), stating that this failure can be explained by their sensitivity to high temperatures which may have been used in the drying process of pollen pellets. ${ }^{6}$ Oliveira, on the other hand, in the assessment of the contents of these vitamins in fresh pollen and their behavior after the process of dehydration, concluded that there was a loss of antioxidant vitamins (vitamin $\mathrm{C}, \mathrm{E}$ and $\beta$-carotene, as well as pro-vitamin A) after the process of dehydration of pollen. ${ }^{7}$

There are no doubts about the beneficial actions of bee pollen to human health. Nevertheless, there are basic questions pending to be clarified in order to ensure the quality of the product for consumption, from the monitoring of its production, preparation and storage. ${ }^{8}$ The Normative Instruction No. 3 of MAPA does not foresee the expiration date of dried bee pollen. ${ }^{1}$ Barreto et al., while gathering information on package for preservation of dried bee pollen from seven different Brazilian states, found expiry periods on the labels of these packages ranging from six months to three years. ${ }^{9}$

Barreto, in assessing the shelf life of dried bee pollen through sensory and centesimal composition analysis, concluded that this shelf life varies depending on the storage temperature. ${ }^{10}$ According to the organoleptic analysis, the pollen has become unfit for consumption after 240 days at room temperature and after 360 days in temperatures of $-12{ }^{\circ} \mathrm{C}$. Because foods are not necessarily consumed immediately

\footnotetext{
*e-mail: ligiabi@usp.br
}

after their manufacturing, such as in the case of pollen, and since the content of vitamins can be affected by several factors such as the type of packaging and the conditions and time of storage, this study aims to evaluate the stability of antioxidant vitamins (vitamins $\mathrm{C}, \mathrm{E}$ and $\beta$-carotene) of dried bee pollen over a one-year period of storage.

\section{EXPERIMENTAL}

\section{Material}

Six different batches of recently collected bee pollen samples were obtained directly from the commercialization warehouse of bee products "PRONATU Laboratory of Natural Products Ltd." located in the State of Sao Paulo (city of Pariquera-Açu). The samples were collected between 23/02/2007 and 09/04/2007, with a one-week space between batches. 15 hives of bees Apis mellifera were used. In the company, each sample was homogenized in order to withdraw $200 \mathrm{~g}$ of fresh pollen to be sent to the laboratory. The remaining pollen was subject to the process of drying in a laboratory sterilizer from the brand Ballardin ${ }^{\circledR}$ adjusted to the temperature of $45^{\circ} \mathrm{C}$ for approximately $6 \mathrm{~h}$. The dried samples were sent to the laboratory in their trade packaging (45 g transparent plastic).

The batches were designated by letters of the alphabet (A, B, C, D, E and F). The fresh samples received were analyzed at once and the batches of dehydrated pollen were divided as the following: 4 packages were analyzed immediately upon entry, in order to compose the Time $0 ; 4$ packages were stored in freezer, and tests were conducted 6 months after the acquisition (Time1) and after a year of storage (Time 2); 4 packages were stored at room temperature, and tests were conducted six months after the acquisition (Time 1) and after a year of storage (Time 2); 4 packages were also stored at room temperature, but these were protected from light exposure with the use of aluminum foil, and tests were conducted 6 months after the acquisition (Time 1) and after a year of storage (Time 2).

\section{Methods}

\section{Determination of vitamin $C$}

This has been achieved using an adapted titulometric method, based on the reduction of 2,6-dichlorophenol-indophenol (DCPIP) by ascorbic acid, according to AOAC. ${ }^{11}$ 


\section{Determination of Vitamin $E$}

This has been achieved by high-performance liquid chromatography (HPLC), as described by Presoto, Rios and Almeida-Muradian and Oliveira. ${ }^{7,12}$

\section{Determination of the total Carotenoids and $\beta$-carotene}

This has been achieved by open column chromatography (OCC), as described by Rodriguez-Amayae Oliveira, in the samples that composed the Time $0 .^{7,13}$ After 6 and 12 months of storage, the $\beta$-carotene was quantified by HPLC, based on the procedure described by Ribeiro et al., with some adjustments. ${ }^{14}$

\section{Statistical analysis}

After observing the normal distribution and homogeneity of the variance, the following tests were adopted: Student's t test to compare the average concentrations of vitamins in fresh and dehydrated pollen; Bidimensional Analysis of Variance (Two-way ANOVA) followed by Duncan test, in order to make the comparison regarding the stability of vitamins ( $\mathrm{C}, \mathrm{E}$ and $\beta$-carotene) of bee pollen in different time conditions (0, 6 and 12 months) and storage conditions (light, dark and freezer). The results were expressed as an average of the results in triplicate \pm standard deviation. All statistical analysis was performed using the program Statistica, with the adoption of a 5\% significance level $(\mathrm{p}<0.05) .{ }^{15}$

\section{RESULTS AND DISCUSSION}

\section{Analysis of fresh and dehydrated pollen}

In the analysis that were carried out, the three vitamins proposed in this work have been identified (vitamin $\mathrm{C}, \mathrm{E}$ and $\beta$-carotene, as pro-vitamin A) as shown in Tables 1 and 2.
It is observed that the concentration of vitamin $\mathrm{C}$ from the fresh samples, that is, those with higher humidity, is smaller than the processed samples from the same batch, with a statistically significant difference between them $(p=0.037325)$. It is suspected that the ascorbic acid, which is more unstable in solution, has been rapidly degraded in the fresh samples during their storage, in the day the pollen was dried, transported to the laboratory and stored in freezer prior to analysis (total of approximately 5 to 6 days). This fact was also observed by Oliveira, who found higher levels of vitamin $\mathrm{C}$ in samples of dried bee pollen, concluding that during the period of storage of fresh bee pollen in freezer, losses of vitamin $\mathrm{C}$ occurred and that the process of dehydration, while promoting vitaminic loss, successively, helps conserve the levels of this vitamin. ${ }^{7}$

The results found in this study are similar to those described by Szczesna et al., who observed average values of vitamin C of $140 \mu \mathrm{g} / \mathrm{g}$ $(n=2)$ in Polish samples of bee pollen. ${ }^{16}$ Oliveira, however, found superior results when she analyzed the content of vitamin $C$ in samples of pollen $(n=10)$ that came from the town of Pindamonhangaba, São Paulo. The values founded ranged from 273.9 to $560.3 \mu \mathrm{g} / \mathrm{g}$ in the fresh samples and from 152.8 to $542.2 \mu \mathrm{g} / \mathrm{g}$ in the processed samples. ${ }^{7}$

The concentration of vitamin $\mathrm{E}$ in bee pollen ranged from 19.43 to $43.00 \mu \mathrm{g} / \mathrm{g}$ in the fresh samples and from 16.27 to $38.64 \mu \mathrm{g} / \mathrm{g}$ in the processed samples. Similar results were found by Oliveira ranging from 13.5 to $42.5 \mu \mathrm{g} / \mathrm{g}$ in the fresh samples and from 8.2 to 32.4 $\mu \mathrm{g} / \mathrm{g}$ in the processed samples. ${ }^{7}$ The process of dehydration of the bee pollen was responsible for an average loss of $18.7 \%$ of the contents of vitamin E, but with no statistically significant difference between fresh and processed samples.

The concentration of total carotenoids of fresh bee pollen ranged from 27.08 to $344.6 \mu \mathrm{g} / \mathrm{g}$ and in the processed samples from 25.34 to $268.5 \mu \mathrm{g} / \mathrm{g}$. As for the $\beta$-carotene, the results ranged from 3.77 to 99.27

Table 1. Concentration of vitamins $\mathrm{C}$ and $\mathrm{E}$ in samples of fresh and dehydrated bee pollen and its loss after processing

\begin{tabular}{|c|c|c|c|c|c|c|}
\hline \multirow[b]{2}{*}{ Batches } & \multicolumn{3}{|c|}{ Vitamin $C(\mu \mathrm{g} / \mathrm{g})^{*}$} & \multicolumn{3}{|c|}{ Vitamin E $(\mu \mathrm{g} / \mathrm{g})^{*}$} \\
\hline & $\begin{array}{l}\text { Fresh } \\
\text { ** }\end{array}$ & $\begin{array}{c}\text { Dehydrated } \\
* *\end{array}$ & $\begin{array}{l}\text { Apparent in- } \\
\text { crease }(\%)\end{array}$ & Fresh & Dehydrated & $\begin{array}{c}\text { Loss } \\
(\%)\end{array}$ \\
\hline A & $14 \pm 0.25$ & $114 \pm 1.62$ & 87.7 & $43.00 \pm 3.61$ & $38.64 \pm 2,72$ & 10.2 \\
\hline B & $52 \pm 2,47$ & $124 \pm 3.94$ & 58.1 & $19.43 \pm 1.70$ & $16.27 \pm 0.38$ & 16.3 \\
\hline $\mathrm{C}$ & $119 \pm 1,96$ & $340 \pm 11.4$ & 65.0 & $25.94 \pm 2.21$ & $20.54 \pm 1.30$ & 20.8 \\
\hline $\mathrm{D}$ & $67 \pm 0,46$ & $126 \pm 4.88$ & 46.8 & $22.47 \pm 0.65$ & $18.42 \pm 0.47$ & 18.0 \\
\hline $\mathrm{E}$ & $15 \pm 0,76$ & $127 \pm 2.08$ & 88.2 & $28.18 \pm 1.12$ & $21.06 \pm 1.76$ & 25.3 \\
\hline $\mathrm{F}$ & $62 \pm 2.16$ & $144 \pm 4.49$ & 56.9 & $37.19 \pm 1.42$ & $32.27 \pm 1.53$ & 13.2 \\
\hline
\end{tabular}

*The tests were carried out in triplicate and the results expressed in Average \pm Standard Deviation. **Averages with a statistically significant difference $(\mathrm{p}<0.05)$, according to the Student's t-test.

Table 2. Concentration of total carotenoids, $\beta$-carotene and its pro-vitaminic A value in samples of fresh and dehydrated bee pollen and its loss due to processing

\begin{tabular}{|c|c|c|c|c|c|c|c|}
\hline \multirow{2}{*}{ Batches } & \multicolumn{3}{|c|}{ Total Carotenoids $(\mu \mathrm{g} / \mathrm{g})^{*}$} & \multicolumn{3}{|c|}{$\beta$-carotene $(\mu \mathrm{g} / \mathrm{g})^{*}$} & \multirow{2}{*}{$\begin{array}{c}\text { Pro-vitamin A } \\
\quad(\mu \mathrm{g} / \mathrm{g})\end{array}$} \\
\hline & Fresh & Dehydrated & $\%$ (loss) & Fresh & Dehydrated & $\%$ (loss) & \\
\hline A & $42.77 \pm 2.97$ & $40.62 \pm 4.89$ & 5.0 & $6.96 \pm 0.44$ & $6.65 \pm 0.29$ & 4.5 & 0.55 \\
\hline B & $27.08 \pm 1.64$ & $25.34 \pm 1.20$ & 6.4 & $3.77 \pm 0.10$ & $3.14 \pm 0.09$ & 17.5 & 0.26 \\
\hline $\mathrm{C}$ & $36.31 \pm 4.97$ & $33.95 \pm 2.95$ & 6.5 & $5.95 \pm 0.35$ & $5.05 \pm 0.03$ & 15.1 & 0.42 \\
\hline D & $344.6 \pm 24.6$ & $268.5 \pm 14.9$ & 22.1 & $99.27 \pm 2.45$ & $77.88 \pm 5.01$ & 21.6 & 6.48 \\
\hline $\mathrm{E}$ & $138.4 \pm 14.6$ & $103.3 \pm 9.2$ & 25.4 & $29.84 \pm 2.59$ & $25.19 \pm 1.80$ & 15.6 & 2.10 \\
\hline $\mathrm{F}$ & $137.1 \pm 6.0$ & $117.2 \pm 16.8$ & 14.5 & $22.13 \pm 0.83$ & $17.83 \pm 1.91$ & 19.4 & 1.49 \\
\hline
\end{tabular}

$*$ The tests were carried out in triplicate and the results expressed in Average \pm Standard Deviation. 
$\mu \mathrm{g} / \mathrm{g}$ in the fresh samples and from 3.14 to $77.88 \mu \mathrm{g} / \mathrm{g}$ in the processed samples. Similar results were found by Oliveira with concentrations of total carotenoids ranging from 4.6 to $178.7 \mu \mathrm{g} / \mathrm{g}$ and $\beta$-carotene ranging from 32.3 and $90.48 \mu \mathrm{g} / \mathrm{g}$ in the processed samples, with special attention given to the absence of $\beta$-carotene in the samples collected in the month of April, 2005. ${ }^{7}$ Muniategui et al., on the other hand, showed values of 0.49 to $242.6 \mu \mathrm{g} / \mathrm{g}$ in total carotenoids sample and obtained on average $10 \mu \mathrm{g} / \mathrm{g}$ of $\beta$-carotene in trade samples of Spanish bee pollen. ${ }^{2}$

In the present work, the process of dehydration of the bee pollen was responsible for an average loss of $13.3 \%$ of the content of total carotenoids and $15.6 \%$ in the content of $\beta$-carotene. However, there was no statistically significant difference between fresh and processed samples, both for total carotenoids and for the $\beta$-carotene. Oliveira observed loss of $40.4 \%$ in the content of total carotenoids and $56.5 \%$ in the content of $\beta$-carotene after the processing of bee pollen $(n=10)$ with a statistically significant difference. ${ }^{7}$ Szczesna et al., however, did not observe any loss of pro-vitamin A after bee pollen dehydration process $(n=1) .{ }^{16}$

The percentage of $\beta$-carotene found in fresh bee pollen ranged from 14 to $29 \%$ compared to total carotenoids. The pro-vitaminic A value of processed samples ranged from 0.26 to $6.48 \mu \mathrm{g}$ of retinol (12 $\mu \mathrm{g}$ of $\beta$-carotene corresponding to $1 \mu \mathrm{g}$ of retinol). According to document $\mathrm{n}^{\mathrm{o}} 31$ from the Ministry of Health, from January 13, 1998, in terms of labelling, solid foods are considered to be a source of a certain vitamin or mineral if they provide $15 \%$ of the dietary reference intake (DRI) in the specified portion of the product. ${ }^{17}$ The DRI of vitamin A for men is 900 $\mu \mathrm{g} / \mathrm{day}$ and for women $700 \mu \mathrm{g} / \mathrm{day} .{ }^{18}$ Therefore, in terms of labelling, only batch $\mathrm{D}$ can be considered a source of this vitamin, due to the amount of $\beta$-carotene that is contains. The recommended daily portion of $25 \mathrm{~g}$ of dry bee pollen would supply $162 \mu \mathrm{g}$ of retinol, that is, $18 \%$ of the recommended daily intake for men and $23 \%$ for women.

\section{Comparison of methodology for analysis of $\beta$-carotene (OCC $x$ HPLC)}

The OCC is a good technique for determining quantity and it is also very useful for separation and purification of carotenoids to be used as patterns in the methods by HPLC. ${ }^{19}$ The HPLC, however, is a technique with greater power of resolution, better reproducible with reusable column and carried out under controlled conditions, without unsuitable exposure to air and light, besides allowing the analysis of a large number of samples in less time. ${ }^{19}$ In view of this, and with the possibility of analyzing samples of pollen after six and twelve months of storage by HPLC, tests were carried out to confirm the compatibility of methods and allow the continuance of the experiment using HPLC for analysis of $\beta$-carotene instead of OCC. The results of the tests to compare the methods showed that there is no statistically significant difference $(\mathrm{p}=0.591696)$ between them, according to the Student's t-test. These results are presented in Table 3.

Table 3. Comparison of the contents of $\beta$-carotene $(\mu \mathrm{g} / \mathrm{g})$ in bee pollen, using OCC and HPLC

\begin{tabular}{|c|c|c|}
\hline \multirow{2}{*}{$\begin{array}{l}\text { Batch } \\
\text { (Sample) }\end{array}$} & \multicolumn{2}{|c|}{ Méthod* } \\
\hline & $\mathrm{OCC}$ & HPLC \\
\hline A (Freezer) & $5.92 \pm 0.39$ & $5.11 \pm 0.33$ \\
\hline A (Dark) & $3.59 \pm 0.20$ & $3.13 \pm 0.07$ \\
\hline A (Light) & $3.52 \pm 0.29$ & $3.30 \pm 0.28$ \\
\hline
\end{tabular}

*Results expressed in dry base though the Average \pm standard deviation of analysis in triplicate, not showing significant difference between the averages, according to the Student's t-test.

Porcu and Rodriguez-Amaya, in analyzing samples of acerola, showed that the content of $\beta$-carotene obtained by the methods of chromatography in open column and high performance liquid chromatography did not differ significantly, showing the reliability of both methods for quantification of $\beta$-carotene. ${ }^{20}$ Almeida-Muradian et al. also observed equivalence between the OCC and HPLC methods in analyzing samples of leafy vegetables $(n=5) .{ }^{21}$ The same was observed by Adewusi and Bradbury when analyzing the content of carotenoid in cassava, concluding in his study that the OCC method is suitable for determination of major carotenoids in foods, since there was no difference in results when analyzed by HPLC. ${ }^{22}$

\section{Analyzes of dehydrated bee pollen after 6 and 12 months of storage}

The analyzed batches were stored in three different ways: at room temperature with exposure to light, at room temperature protected from light, and in freezer. The samples were stored in transparent plastic packaging and labeled according to the one sent by the commercialization warehouse. The results for the analysis of vitamin $\mathrm{C}$ (ascorbic acid), vitamin $\mathrm{E}$ ( $\alpha$-tocopherol) and $\beta$-carotene after six and twelve months of storage are expressed in Tables 4, 5 and 6, respectively.

According to Table 4, we can observe that the storage at room temperature, both in the samples exposed as in the ones protected from light, was responsible for an average loss of $50 \%$ in the concentration of vitamin C. When exposed to light, there was an average reduction

Table 4. Concentration of vitamin C $(\mu \mathrm{g} / \mathrm{g})$ in samples of dehydrated bee pollen after six and twelve months of storage

\begin{tabular}{|c|c|c|c|c|c|c|c|c|c|c|c|c|c|}
\hline \multirow{4}{*}{ Batch } & \multirow{4}{*}{$\begin{array}{c}\text { Time } 0 \\
\mu \mathrm{g} / \mathrm{g}\end{array}$} & \multicolumn{12}{|c|}{ Condition* } \\
\hline & & \multicolumn{4}{|c|}{ Light } & \multicolumn{4}{|c|}{ Dark } & \multicolumn{4}{|c|}{ Freezer } \\
\hline & & \multicolumn{2}{|c|}{6 months } & \multicolumn{2}{|c|}{12 months } & \multicolumn{2}{|c|}{6 months } & \multicolumn{2}{|c|}{12 months } & \multicolumn{2}{|c|}{6 months } & \multicolumn{2}{|c|}{12 months } \\
\hline & & $\mu \mathrm{g} / \mathrm{g}$ & $\begin{array}{r}\text { Loss } \\
(\%)\end{array}$ & $\mu \mathrm{g} / \mathrm{g}$ & $\begin{array}{r}\text { Loss } \\
(\%)\end{array}$ & $\mu \mathrm{g} / \mathrm{g}$ & $\begin{array}{c}\text { Loss } \\
(\%)\end{array}$ & $\mu \mathrm{g} / \mathrm{g}$ & $\begin{array}{c}\text { Loss } \\
(\%)\end{array}$ & $\mu \mathrm{g} / \mathrm{g}$ & $\begin{array}{c}\text { Loss } \\
(\%)\end{array}$ & $\mu \mathrm{g} / \mathrm{g}$ & $\begin{array}{l}\text { Loss } \\
(\%)\end{array}$ \\
\hline A & $114 \pm 1.62^{\mathrm{a}}$ & $53 \pm 1.44^{\mathrm{b}}$ & 53.5 & $50 \pm 2.80^{\mathrm{b}}$ & 56.5 & $64 \pm 4.53^{b}$ & 44.0 & $61 \pm 4.04^{b}$ & 46.3 & $76 \pm 5.30^{\mathrm{a}}$ & 33.4 & $72 \pm 9.84^{b}$ & 37.2 \\
\hline B & $124 \pm 3.94^{\mathrm{a}}$ & $84 \pm 7.24^{b}$ & 32.2 & $84 \pm 5.16^{b}$ & 31.8 & $84 \pm 3.76^{b}$ & 31.8 & $83 \pm 0.53^{b}$ & 33.1 & $99 \pm 7.31^{\mathrm{a}}$ & 20.2 & $91 \pm 12.8^{b}$ & 26.6 \\
\hline $\mathrm{C}$ & $340 \pm 11.5^{\mathrm{a}}$ & $148 \pm 6.68^{b}$ & 56.5 & $106 \pm 2.26^{b}$ & 68.8 & $90 \pm 5.11^{b}$ & 73.6 & $76 \pm 5.72^{b}$ & 77.7 & $301 \pm 9.11^{\mathrm{a}}$ & 11.5 & $284 \pm 2.39^{b}$ & 16.6 \\
\hline D & $126 \pm 4.88^{\mathrm{a}}$ & $47 \pm 6.52^{b}$ & 62.7 & $45 \pm 3.07^{b}$ & 64.0 & $47 \pm 0.53^{b}$ & 62.4 & $40 \pm 1.32^{b}$ & 68.6 & $91 \pm 8.41^{\mathrm{a}}$ & 27.8 & $87 \pm 4.88^{b}$ & 30.7 \\
\hline $\mathrm{E}$ & $127 \pm 2.08^{\mathrm{a}}$ & $52 \pm 2.35^{b}$ & 59.2 & $44 \pm 2.82^{b}$ & 65.4 & $44 \pm 2.95^{b}$ & 65.6 & $41 \pm 3.52^{b}$ & 67.9 & $98 \pm 7.54^{\mathrm{a}}$ & 22.8 & $91 \pm 5.87^{b}$ & 28.3 \\
\hline $\mathrm{F}$ & $144 \pm 4.49^{\mathrm{a}}$ & $79 \pm 3.95^{b}$ & 44.9 & $81 \pm 4.17^{b}$ & 43.8 & $75 \pm 1.92^{b}$ & 47.9 & $78 \pm 4.21^{b}$ & 46.0 & $125 \pm 2.48^{\mathrm{a}}$ & 13.3 & $118 \pm 6.21^{b}$ & 18.4 \\
\hline
\end{tabular}

* Results expressed in dry base though the Average \pm standard deviation of analysis in triplicate. Comparisons of pollen stability under different conditions of time and storage made by Two-way ANOVA followed by Duncan. Statistically significant differences are indicated by the different letters in the columns. 
of 52 and $55 \%$ after 6 and 12 months of storage, respectively. When protected from light, this loss was similar: 54 and 59\% after six and twelve months of storage, respectively. According to the statistical test performed, there were significant differences $(p<0.05)$ between these two conditions when compared to concentrations of vitamin at Time 0 . However, there was no difference between the periods of analysis (6 and 12 months) in both conditions of storage at room temperature. This suggests that when stored at room temperature, vitamin $C$ is rapidly lost, probably due to oscillations in temperature, and, after this initial sharp loss, it becomes quite stable during the storage process.

In the samples that were stored in the freezer, the average percentage of loss was lower, about a half (22\% in 6 months and $26 \%$ in 12 months) when compared to the losses that occurred in storage at room temperature. However, for initial concentrations of vitamin $\mathrm{C}$, there was only statistically significant difference $(\mathrm{p}<0.05)$ after twelve months of storage in freezer. These results indicate that, taking into account the retention of vitamin $\mathrm{C}$ as an index of quality and shelf life of food, it is recommended to store the samples of dried bee pollen in the freezer until consumption.

In relation to vitamin $\mathrm{E}$, Table 5 shows that the storage conditions do not account for drastic losses in its concentrations. When stored in freezer, the average percentages of reduction were 5 and $13 \%$ after 6 and 12 months respectively. Under room temperature conditions, however, there was an average reduction of vitamin around $10 \%$ after 6 months of storage, both when exposed to and protected from light and, after 12 months of storage, the average losses were 18 and $15 \%$ when exposed to light and protected from light, respectively.

Table 6 shows the behavior of $\beta$-carotene over a year under the conditions studied. It can be observed that when stored at room temperature and protected from light, the percentage of loss of $\beta$-carotene in bee pollen ranged from 39 to $91 \%$ after 6 months of storage and 59 to $76 \%$ after 12 months. When protected from light, at room temperature, the percentages were similar to those found when exposed to light, in both periods studied. Meanwhile, when stored in a freezer, there was an average loss of 11 and $12 \%$ on the concentration of $\beta$-carotene in the samples after 6 and 12 months respectively, indicating that this is the best way to store bee pollen when its preservation is taken into consideration. However, according to the statistical test used, there were no significant differences between the studied conditions, or between periods (6 and 12 months).

Szczesna et al., assessed the stability of vitamins in bee pollen from Poland and showed losses of 37 and $90 \%$ in the content of vitamin $C(n=2)$ after 6 and 12 months respectively, of storage at 20 ${ }^{\circ} \mathrm{C} .{ }^{16}$ However, there was no loss of vitamin when the samples were stored for six months at $-20{ }^{\circ} \mathrm{C}$, but there was a loss after 12 months of storage at that temperature $(45 \%)$. As for the concentration of provitamin A in the samples $(n=1)$ of pollen, the authors observed no loss after six months of storage in any of the conditions (20 and -20 ${ }^{\circ} \mathrm{C}$ ) and found only small percentages of reduction (3 and 5\%) after 12 months in these temperatures $\left(20\right.$ and $\left.-20{ }^{\circ} \mathrm{C}\right) .{ }^{16}$

Table 5. Concentration of vitamin E $(\mu \mathrm{g} / \mathrm{g})$ in samples of dried bee pollen after six and twelve months of storage

\begin{tabular}{|c|c|c|c|c|c|c|c|c|c|c|c|c|c|}
\hline \multirow{4}{*}{ Batch } & \multirow{4}{*}{$\begin{array}{c}\text { Time } 0 \\
\mu \mathrm{g} / \mathrm{g}\end{array}$} & \multicolumn{12}{|c|}{ Condition* } \\
\hline & & \multicolumn{4}{|c|}{ Light } & \multicolumn{4}{|c|}{ Dark } & \multicolumn{4}{|c|}{ Freezer } \\
\hline & & \multicolumn{2}{|c|}{6 months } & \multicolumn{2}{|c|}{12 months } & \multicolumn{2}{|c|}{6 months } & \multicolumn{2}{|c|}{12 months } & \multicolumn{2}{|c|}{6 months } & \multicolumn{2}{|c|}{12 months } \\
\hline & & $\mu \mathrm{g} / \mathrm{g}$ & $\begin{array}{r}\text { Loss } \\
(\%) \\
\end{array}$ & $\mu \mathrm{g} / \mathrm{g}$ & $\begin{array}{r}\text { Loss } \\
(\%) \\
\end{array}$ & $\mu \mathrm{g} / \mathrm{g}$ & $\begin{array}{c}\text { Loss } \\
(\%) \\
\end{array}$ & $\mu \mathrm{g} / \mathrm{g}$ & $\begin{array}{c}\text { Loss } \\
(\%)\end{array}$ & $\mu \mathrm{g} / \mathrm{g}$ & $\begin{array}{c}\text { Loss } \\
(\%)\end{array}$ & $\mu \mathrm{g} / \mathrm{g}$ & $\begin{array}{r}\text { Loss } \\
(\%) \\
\end{array}$ \\
\hline A & $38.6 \pm 2.72$ & $36.7 \pm 0.40$ & 5.1 & $24.2 \pm 1.04$ & 37.4 & $37.4 \pm 0.87$ & 3.2 & $27.2 \pm 0.76$ & 29.6 & $37.5 \pm 2.1$ & 2.3 & $24.4 \pm 0.76$ & 36.7 \\
\hline B & $16.3 \pm 0.38$ & $15.8 \pm 0.53$ & 2.8 & $15.9 \pm 0.74$ & 2.5 & $16.8 \pm 0.50$ & - & $16.3 \pm 1.67$ & - & $16.0 \pm 1.73$ & - & $16.3 \pm 0.14$ & - \\
\hline $\mathrm{C}$ & $20.5 \pm 1.30$ & $18.8 \pm 1.08$ & 8.4 & $20.7 \pm 1.19$ & - & $18.7 \pm 1.11$ & 8.8 & $19.8 \pm 1.89$ & 3.4 & $22.0 \pm 1.20$ & - & $22.1 \pm 0.39$ & - \\
\hline D & $18.4 \pm 0.47$ & $21.4 \pm 0.53$ & - & $16.0 \pm 0.09$ & 13.3 & $20.8 \pm 0.13$ & - & $20.3 \pm 1.44$ & - & $24.2 \pm 0.04$ & - & $17.5 \pm 1.89$ & 5.2 \\
\hline E & $21.1 \pm 1.76$ & $18.0 \pm 0.44$ & 14.6 & $15.8 \pm 0.69$ & 25.0 & $17.0 \pm 0.57$ & 19.4 & $15.2 \pm 2.16$ & 28.0 & $19.0 \pm 1.92$ & 9.7 & $16.4 \pm 0.53$ & 22.1 \\
\hline $\mathrm{F}$ & $32.3 \pm 1.53$ & $23.9 \pm 0.75$ & 26.1 & $22.1 \pm 0.95$ & 31.5 & $24.0 \pm 1.28$ & 25.6 & $22.9 \pm 2.42$ & 29.0 & $26.8 \pm 1.98$ & 17.1 & $26.9 \pm 2.68$ & 16.6 \\
\hline
\end{tabular}

*Results expressed in dry base though the Average \pm standard deviation of analysis in triplicate. Comparisons of bee pollen stability under different conditions of time and storage made by Two-way ANOVA followed by Duncan.

Table 6. Concentration of $\beta$-carotene $(\mu \mathrm{g} / \mathrm{g})$ in samples of dried bee pollen after six and twelve months of storage

\begin{tabular}{|c|c|c|c|c|c|c|c|c|c|c|c|c|c|}
\hline \multirow{4}{*}{ Batch } & \multirow{4}{*}{$\begin{array}{c}\text { Time } 0 \\
\mu \mathrm{g} / \mathrm{g}\end{array}$} & \multicolumn{12}{|c|}{ Condition * } \\
\hline & & \multicolumn{4}{|c|}{ Light } & \multicolumn{4}{|c|}{ Dark } & \multicolumn{4}{|c|}{ Freezer } \\
\hline & & \multicolumn{2}{|c|}{6 months } & \multicolumn{2}{|c|}{12 months } & \multicolumn{2}{|c|}{6 months } & \multicolumn{2}{|c|}{12 months } & \multicolumn{2}{|c|}{6 months } & \multicolumn{2}{|c|}{12 months } \\
\hline & & $\mu \mathrm{g} / \mathrm{g}$ & $\begin{array}{r}\text { Loss } \\
(\%)\end{array}$ & $\mu \mathrm{g} / \mathrm{g}$ & $\begin{array}{r}\text { Loss } \\
(\%)\end{array}$ & $\mu \mathrm{g} / \mathrm{g}$ & $\begin{array}{c}\text { Loss } \\
(\%)\end{array}$ & $\mu \mathrm{g} / \mathrm{g}$ & $\begin{array}{c}\text { Loss } \\
(\%)\end{array}$ & $\mu \mathrm{g} / \mathrm{g}$ & $\begin{array}{c}\text { Loss } \\
(\%)\end{array}$ & $\mu \mathrm{g} / \mathrm{g}$ & $\begin{array}{c}\text { Loss } \\
(\%)\end{array}$ \\
\hline A & $6.65 \pm 0.29$ & $3.30 \pm 0.28$ & 50.4 & $2.61 \pm 0,14$ & 60.8 & $3.13 \pm 0.07$ & 53.0 & $1.59 \pm 0.03$ & 76.0 & $5.11 \pm 0.33$ & 23.2 & $4.59 \pm 0.30$ & 31.1 \\
\hline B & $3.14 \pm 0.09$ & $1.91 \pm 0.08$ & 39.1 & $1.28 \pm 0,03$ & 59.3 & $1.87 \pm 0.06$ & 40.3 & $0.95 \pm 0.07$ & 69.9 & $3.05 \pm 0.08$ & 2.8 & $3.10 \pm 0.18$ & 1.4 \\
\hline $\mathrm{C}$ & $5.05 \pm 0.03$ & $1.99 \pm 0.22$ & 60.7 & $1.82 \pm 0,14$ & 63.9 & $1.96 \pm 0.14$ & 61.1 & $1.53 \pm 0.06$ & 69.7 & $4.41 \pm 0.22$ & 12.7 & $4.57 \pm 0.18$ & 9.6 \\
\hline D & $77.9 \pm 5.01$ & $39.4 \pm 0.57$ & 49.4 & $18.9 \pm 0,40$ & 75.7 & $43.4 \pm 0.66$ & 44.2 & $18.4 \pm 0.53$ & 76.3 & $77.6 \pm 2.28$ & 0.4 & $72.9 \pm 0.75$ & 6.5 \\
\hline E & $25.2 \pm 1.80$ & $12.5 \pm 0.65$ & 50.3 & $6.67 \pm 0,07$ & 73.5 & $11.5 \pm 0.75$ & 54.2 & $5.85 \pm 0.25$ & 76.8 & $20.7 \pm 1.15$ & 17.9 & $23.3 \pm 0.22$ & 7.5 \\
\hline F & $17.8 \pm 1.91$ & $9.00 \pm 0.45$ & 49.5 & $5.13 \pm 0,06$ & 71.2 & $9.52 \pm 0.26$ & 46.4 & $5.03 \pm 0.23$ & 71.8 & $16.1 \pm 0.11$ & 9.9 & $14.9 \pm 0.32$ & 16.5 \\
\hline
\end{tabular}

*Results expressed in dry basis though the Average \pm standard deviation of analysis in triplicate. Comparisons of bee pollen stability under different conditions of time and storage made by Two-way ANOVA followed by Duncan. 


\section{CONCLUSIONS}

In face of the results presented here, it can be concluded that the storage in freezer was the most efficient condition for the conservation of the three vitamins, and the loss during storage at room temperature when exposed to light and protected from light was similar. When considering the three conditions studied, the vitamin $\mathrm{E}$ appears to be better preserved during storage when compared to vitamin $\mathrm{C}$ and $\beta$-carotene.

\section{ACKNOWLEGMENTS}

The company PRONATU Laboratory of Natural Products Ltd., for the supply of samples; Conselho Nacional de Desenvolvimento Científico e Tecnológico - CNPq (National Council for Scientific and Technological Development) for the granted scholarships and to Fundação de Amparo à Pesquisa do Estado de São Paulo - FAPESP - Process No. 06/59187-9 (Foundation of Support for Research of the State of Sao Paulo) for the financial support.

\section{REFERENCES}

1. http://e-legis.bvs.br/leisref/public/showAct.php?id=12479\&word, acessada em Fevereiro 2010.

2. Muniategui, S.; Sancho, M. T.; Lopez, J.; Huidobro, J. F.; Simal, J.; J. Apicultural Res. 1990, 29, 147.

3. Campos, M. G.; Cunha, A.; Markham, K. R. Em Bee pollen: composition, properties and application; Mizrahi, A.; Lensky, Y., eds.; Plenum Press: New York, 1997, p. 93-100.

4. Herbet Jr., E. W.; Shimanuki, H.; Apidologie 1978, 9, 33.

5. Albalá-Hurtado, S.; Veciana-Nogués, M. T.; Izquierdo-Pulido, M.; Mariné-Font, A.; J. Chromatogr., A 1997, 778, 247.
6. Almeida-Muradian, L. B.; Pamplona, L. C.; Coimbra, S.; Barth, O. M.; J. Food Compos. Anal. 2005, 18, 105.

7. Oliveira, K. C. L. S.; Dissertação de Mestrado, Universidade de São Paulo, Brasil, 2006.

8. Barreto, L. M. R. C.; Funari, S. R. C.; Orsi, R. O.; Dib, A. P. S.; Produção de pólen no Brasil, Cabral: Taubaté, 2006.

9. Barreto, L. M. R. C.; Funari, S. R. C.; Orsi, R. O.; Boletim de Indústria Animal 2005, 62, 167.

10. Barreto, L. M. R. C.; Tese de Doutorado, Universidade Estadual Paulista Julio de Mesquita Filho, Brasil, 2004.

11. Association of Official Analytical Chemists; Official methods of analysis of AOAC international, $16^{\text {th }}$ ed., AOAC: Arlington, 1995, cap. 45.

12. Presoto, A. E. F.; Rios, M. D. G.; Almeida-Muradian, L. B.; Bollettino dei Chimici Igienisti 2000, 51, 111.

13. Rodriguez-Amaya, D. B.; A guide to carotenoid analysis in foods, ILSI Press: Washington, 2001.

14. Ribeiro, S. M. R.; Queiroz, J. H.; Queiroz, M. E. L. R.; Campos, F. M.; Sant'Ana, H. M. P.; Plant Foods for Human Nutrition 2007, 62, 13.

15. Statistica; Version 8.0 for Windows; StatSoft: Tulsa, 2007.

16. Szczesna, T.; Rybak-Chimielewska, H.; Bornus, L.; Apiacta 1991, 2.

17. http://e-legis.bvs.br/leisref/public/showAct.php?id=64\&word., acessada em Fevereiro 2010

18. http://books.nap.edu/catalog.php?record_id=10026., acessada em Fevereiro 2010

19. Kimura, M.; Rodriguez-Amaya, D. B.; Boletim da Sociedade Brasileira de Ciência e Tecnologia de Alimentos 2003, 37, 74.

20. Porcu, O. M.; Rodriguez-Amaya, D. B.; J. Sci. Food Agric. 2006, 86, 1916.

21. Almeida-Muradian, L. B.; Rios, M. D. G.; Sasaki, R.; Bollettino Chimico Farmaceutico 1998, 137, 290.

22. Adewusi, S. R. A.; Bradbury, J. H.; J. Sci. Food Agric. 1993, 62, 375 